\title{
Sosyal Sermaye ve Sosyal Medya: Demokrasi ve Vatandaşlık Hakkında Bir Araştırma*
}

\section{A Research on Social Capital and Social Media: Democracy and Citizenship}

\author{
İsmail ACUN ${ }^{* *}$ \\ Cemil YÜCEL ${ }^{* \star *}$ \\ Nur Leman BALBAĞ $\check{G}^{\star * \star *}$ \\ Serap IR $^{* \star * \star *}$ \\ Cüneyt BELENKUYU ${ }^{\star \star * * * *}$
}

\begin{abstract}
Öz. Bu araştırmanın amacı Türkiye'deki sosyal bilim alanlarında eğitim almakta olan üniversite öğrencilerinin sahip olduğu sosyal sermaye birikimi ile sosyal medya kullanımları ve demokratik vatandaşlık davranışları arasında ilişkilerin ortaya çıkarılmasıdır. Araştırma nitel araştırma yaklaşımlarından olgu bilim ile desenlemiştir. Araştırmanın verileri 2015-2016 Bahar döneminde çeşitli devlet üniversitelerinde, sosyal bilim alanında eğitim almakta olan 11 öğrenciyle gerçekleştirilen yarı yapılandırılmış görüşmelerle toplanmıştır. Veriler içerik analizine tabii tutulmuştur. Yapılan analizler sonucunda sosyal sermaye, sosyal medya, demokrasi ve bilgi kaynakları olmak üzere dört ana tema ortaya çıkmıştır. Öğrencilerin kaynaştırıcı ve bağlayıcı olmak üzere iki çeşit sosyal sermaye sahip oldukları, sosyal medyayı ağ kurma, araştırma, siyasal grup oluşturma ve eğlence amaçlı kullandıkları görülmektedir. Herhangi bir bilgiye ihtiyaçları olduğunda ise bilimsel bilgi, sosyal medyadan edindikleri bilgi, otoriteye ve tecrübeye dayalı bilgileri kullandıkları tespit edilmiştir. Ayrıca demokrasiye yönelik görüşleri de onları algıları, vatandaşlık özellikleri ve demokratik sistem kurumlarına karşı duydukları güven olarak ortaya çıkmıştır.
\end{abstract}

Anahtar Kelimeler: Sosyal sermaye, demokrasi, sosyal medya, güven, vatandaşlık.

\begin{tabular}{|c|}
\hline 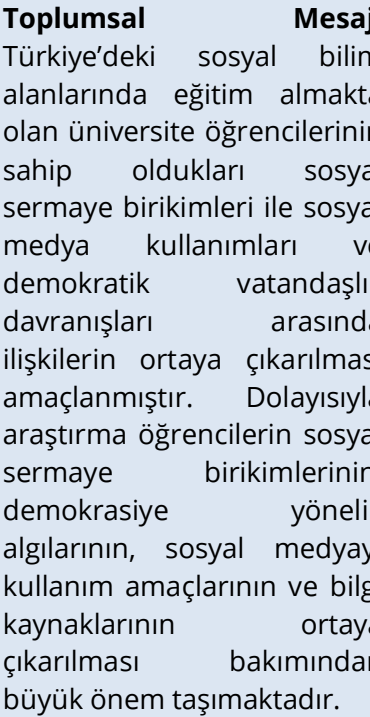 \\
\hline
\end{tabular}

Abstract. The aim of the study is to investigate the relationship between social capital, social media use and democratic citizenship behaviors of university students studying at social science department at different Turkish state universities. The research employs a qualitative approach. The data were collected during 2015-2016 spring semester. 11 students were involved in semi-structured interviews. The students at the time of the study were studying social sciences departments of different state universities in Turkey. Data was subjected to content analysis. There were four categories after data analysis; social capital, social media, democracy and sources of information. Analysis shows that students have both bonding and bridging social capital. They use social media for networking, research, interact with political groups and fun. When they need any kind of information they use social media, scientific resources, authority and their own life experiences. Their opinions towards democracy is categorized as their perception of democracy, trust in democratic institutions and their citizenship features.

Keywords: Social capital, democracy, social media, trust, citizenship.
Public Interest Statement. The aim of the study is to investigate the relationship between social capital, social media use and democratic citizenship behaviors of university students studying at social science department at different Turkish state universities. This research is very important to find out students' social capital, social media use, democratic citizenship behaviors and information sources.

\footnotetext{
* Bu çalışma, yürütücülüğü İsmail ACUN tarafından yapılan 114K190 numaralı TÜBiTAK araştırma projesinin verilerinin bir kısmı kullanılarak ortaya çıkmıştır.

** Doç. Dr., Eskişehir Osmangazi Üniversitesi, Türkçe ve Sosyal Bilimler Bölümü, iacun@ogu.edu.tr

*** Prof. Dr., Eskişehir Osmangazi Üniversitesi, Eğitim Bilimleri Bölümü, cemilyucel@gmail.com

**** Dr. Uşak Üniverstesi, Temel Eğitim Bölümü, nurleman.goz@usak.edu.tr

${ }^{* \star \star \star *}$ Sinop Üniversitesi, Eğitim Fakültesi, Eğitim Bilimleri Bölümü, serap iri@hotmail.com

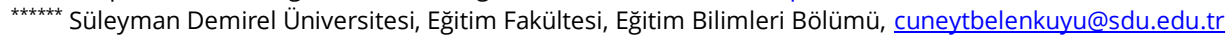




\section{GíRiş}

Günümüzde bireylerin sosyal, çevresel, siyasal ve küresel konulara yönelik olarak sadece bireysel olarak aktif olmaları yetersiz kalmaktadır. Sağlıkı bir demokrasi ortamının sağlanabilmesi için bireysel aktivitelerinin yanında başka bireyler, kurumlar ve sivil toplum kuruluşlarıyla birlikte hareket ederek mevcut sorunların çözümüne katkı sağlamaya çalışılmalıdır. Özellikle kamuoyunu etkileyen konularda internet ve sosyal medya önemli araçlar olarak bireyler, sendika, siyasi partiler ve özellikle çevrimiçi olarak oluşmuş cemiyetler vs. tarafından etkin bir şekilde kullanılmaya çalışılmaktadır. Bu yüzden sosyal sermaye, demokrasi ve sosyal medya araçları arasındaki ilişkinin ortaya koyulması büyük önem taşımaktadır.

\subsection{Amaç}

Araştırmanın amacı Türkiye'deki sosyal bilim alanlarında eğitim almakta olan üniversite öğrencilerinin sahip oldukları sosyal sermaye birikimi ile sosyal medya kullanımları ve demokratik vatandaşlık davranışları arasındaki ilişkilerin ortaya çıkarılmasıdır. Bu amaç doğrultusunda şu sorulara yanıt aranmıştır.

- Öğrencilerin sosyal sermaye birikimleri nasıldır?

- Öğrenciler demokrasiyi nasıl anlamlandırmaktadır?

- Öğrencilerin demokratik sistem kurumlarına karşı görüşleri nelerdir?

- Öğrenciler herhangi bir bilgiye ulaşmak istediklerinde hangi bilgi kaynaklarına başvurmaktadırlar?

- Öğrencilerin sosyal medyayı kullanma amaçları nelerdir?

\subsection{Problem}

Sosyal sermayeye yönelik alanyazın incelendiğinde sosyal sermayenin ne olduğu ve boyutları konusunda ortak bir tanım bulunmamaktadır. Sosyal sermayenin temel özellikleri incelendiğinde teorisyenlerin ortak olarak sosyal sermayeyi insanların ilişkileri yoluyla kendi sağladıkları yararlar ve olanaklar olarak tanımladıkları görülmektedir (Coleman, 1988; Putnam, 2000; Lin, 2005). OECD’nin (2011)' nin raporuna göre sosyal sermayenin kaynağı antropoloji literatüründe insanın cemiyet olma içgüdüsü iken sosyoloji literatüründe göre sosyal normlar ve motivasyon olgusunu sosyal olarak ele alınır. Sosyal sermayenin çıkış noktası olan ekonomi alan yazınında çeşitli grup faaliyetlerinin devamının sağlanması ve bireylerin kişisel faydalarını en üst seviyeye çıkarmak için diğer bireylerle iletişim halinde olması varsayımı olarak yer almaktadır (OECD, 2001, s.40). Tocqueville'den başlayarak sivil toplum örgütlerinin demokrasiyle ilişkisi bu sosyal örgütlenmelerle sağlandığına dair bir gelenek mevcuttur (Van Deth, 2010). Granovetter (1973) kavramsallaştırdığı güvene dayalı zayıf ilişkiler ağının sosyal sermayenin güçlenmesine ne kadar büyük katkı yaptığına dair argümanı sonradan Putnam (1993 akt. Pattie, Seyd ve Whiteley, 2003) tarafından kaynaştırııı sosyal sermaye olarak adlandırılacak olan sosyal sermayenin iki temel boyutundan birisini oluşturmuştur. Bu araştırmada bonding için kaynaştırıcı ve bridging için bağlayıcı kavramları kullanılmıştır. Buna göre sosyal sermaye kaynaştırıcı ve bağlayıcı olarak iki türlüdür. Kaynaştırıcı sosyal sermaye bireylerin ancak kendilerinin şahsen tanıdığı ve birbirine destek olduğu kapalı grup ilişskilerindeki güven esasına dayalı bir sosyal sermayedir (Putnam, 2000). Bağlayıcı sosyal sermaye ise bireyin toplumun herhangi bir kesimine mensup kişi ve grupları ile oluşturduğu işbirliği ağları ve birlikte yürüttüğü gönüllü sosyal, siyasal ve çevresel faaliyetleri içeren genel bir güven esasına dayalı sosyal sermaye türüdür (Putnam, 2000; Lin, 2005). Bireylerin sosyal sermaye birikimleriyle sahip oldukları vatandaşlık özellikleri toplumlarda demokrasinin gelişimini etkilemektedir.

Demokratik toplumların en belirgin özelliklerinden birisi o toplumu oluşturan bireylerin aktif vatandaşlık davranışlarını göstermesidir. Aktif vatandaşlık kavramının kimi zaman sosyal sermaye teorisinde tartışılan gönüllü katılım ile benzeştiği söylenmiştir (Pattie, Seyd ve Whiteley, 2003; Dalton, 2008; Zmerli, 2010). Ancak aktif vatandaşlık bireyin, bireysel olarak vatandaşlık hak ve 
sorumluluklarını yerine getirmesini de içermektedir. Kişinin bireysel tüketici olarak haklarını araması bunun bir örneği olarak verilebilir. Bununla birlikte demokratik toplumlarda aktif vatandaşlık davranışları; bireysel ve topluluk olarak haklarını araması, siyasi partilere ve etkinliklerde katılımda bulunması, küresel sorunların çözümü için gönüllü olarak topluluklara katılması, toplum için gönüllü çalışmalarda bulunması gibi işbirliği gerektiren güven esasına dayalı faaliyetlerda bulunmayı öngörmektedir. Bu yüzden sosyal sermaye ve aktif vatandaşlık arasında doğrudan hem teorik hem de pratik bir bağ olduğu anlaşılmaktadır (Pattie, Seyd ve Whiteley, 2003; Dalton, 2008; Zmerli, 2010). Bu bağlamda bu çalışmada bireylerin demokrasiye yönelik algıları ve aktif vatandaşlık davranışlarının ortaya konulması büyük önem teşkil etmektedir. Ayrıca Sosyal sermaye teorisinde, demokratik toplumların sağlıklı işleyişine yönelik en temel göstergelerden birinin güven olduğu vurgulanmaktadır. Güven hem bireylerin toplumu oluşturan diğer bireylere karşı duydukları güven hem de demokratik sistem kurumlarına karşı duydukları güven bağlamında önem kazanmaktadır. Güven toplumsal bütünlüğün, ekonomik etkililiğin ve sağlam bir demokrasinin işleyişinde sosyal sermayenin belki de en önemli kavramını oluşturmaktadır. Çünkü güven, gönüllü katılım ağlarının oluşmasını ve böylece sosyal, siyasal ve çevresel sorunların çözülmesi yoluyla bireyin bireysel olarak sağlayamayacağı faydanın ortaya çıkmasını sağlamaktadır. Bu yüzden de sosyal sermaye teorisinin temel noktasını oluşturmaktadır (Newton, 2001). Bireyin çevresine karşı duyduğu güven kendi yaşantılarına dayanırken, siyasal sistem ve kurumlarına duyduğu güven medya aracılığıyla edindiği bilgilere dayanmaktadır. Dolayısıyla demokratik sistemin işleyişinin en önemli araçlarından birisi bağımsız bir medyanın varlığıdır. Internet ve onun araçlarının insan hayatına girmesinden önceki dönemde bile medya, öneminden dolayı siyasal sistemde yargı, yürütme ve yasamanın yanında 4. erk olarak adlandırılmaktaydı (Erdoğan, 1999). Internetin bütün dünyada sıradan insanların bile hayatını çok derinden etkilediği günümüzde ise demokratik sistemin işleyişi, siyaset kurumuna ve kuruluşlarına yönelik algılanan güveni daha da çok etkiler hale gelmiştir. Bu durumda kişinin güven duygusunun oluşmasında birçok yeni faktör devreye girmektedir. Bunlar arasında medya araçlarının sahipliği ile siyasal iktidarlar arasındaki ilişki, medya okuryazarlığı ve bireyin başvurduğu bilgi kaynakları vardır (Newton, 2002). Dolayısıyla bireylerin bilgi almak için başvurdukları bilgi kaynakları büyük önem taşımaktadır.

Bireyler günlük yaşamda karşılaştıkları problemleri çözmede farklı akıl yürütme metodolojileri ve farklı bilgi kaynaklarını kullanmaktadırlar. Başvurulan bu bilgi kaynakları pek çok araştırmacı tarafından değişik şekillerde sınıflandırılmıştır. Karasar (2013) bilgi kaynaklarını; önceki uygulamalar, (gelenekler/emsal), otorite figürleri, kişinin kendi deneyimleri ve bilim olarak sıralamıştır. Günümüzde bilgi ve iletişim teknolojilerinde meydana gelen hızlı gelişme, özellikle insanların internet ve sosyal medyayı kullanımına paralel olarak başvurdukları bilgi kaynaklarında değişime neden olabilmektedir. Bu bağlamda sosyal medya bilgi kaynağı olarak ayrı başlık altında da sınıflandırılabilmektedir. Çünkü sosyal medyanın, son yıllarda meydana gelen büyük toplumsal olaylar üzerinde önemli etkileri olduğu görülmektedir. Bu tip olaylarda sosyal medya insanların hızlı bir şekilde örgütlenmesine büyük katkı sağlamıştır. Bu da insanların sosyal medyada paylaşılan bilgiye duydukları güvenin bir göstergesidir. Sosyal medya sosyal sermaye boyutundan incelendiğinde farklı amaçları gerçekleştirmek amacıyla kitleleri organize etme ve harekete geçirmek için kullanıırken aynı zamanda resmi kanallar vasıtasıyla ulaşılamayan en güncel bilgilerle insanların haberler konusunda güncel kalmalarını sağlamaktadır (Lerman ve Ghosh, 2010). Sosyal medya bireyler için özel ve sabit bir sosyal adres oluşturması dolayısıyla mekânsal, zamansal ve sosyal uzakıı bağlamında bir kısıtlama olmaksızın bireyler için bağlantılarına ulaşmayı ve bunu tekrar tekrar gerçekleştirebilmeyi sağlamaktadır. Bu bağlamda sivil demokratik katıım ve sosyal medya arasındaki ilişkide aracı değişken olarak sosyal sermayeyi inceleyen Shin ve Choi (2017) sosyal medya aracılığıyla sosyal olay ve olgular konusunda daha aktif olarak görüşlerini paylaşan bireylerin diğer bireylerle ya da gruplarla sosyalleştiğini ve geliştirdikleri sosyal sermayenin de bireylerin sivil katıımlarını artırdığını ifade etmiştir. Arap baharı diye adlandırılan Libya, Tunus ve Mısır gibi ülkelerde uzun yıllardır işbaşında bulunan iktidarların yıkılmasını sağlayan olayların planlanmasında ve uygulanmasında sosyal medyanın çok önemli rol oynadığı bilinmektedir 
(Babacan, Haşlak ve Hira, 2011). Türkiye'de de özellikle Twitter ve Facebook gibi sosyal medya araçlarının kullanım sürelerindeki artış bu bağlamda bireylerin politik ve sosyal meselelerin odağına inmelerine daha fazla olanak tanımaktadır. Shin ve Choi (2017) makro düzeyde bireylerin fikir ve görüşlerini bildirerek demokratik katılım göstermelerinin yanı sıra mikro düzeyde de insanların sosyal medyada sosyal ilişkiler kurarak ve bu ilişkileri sürdürerek sosyal sermayelerini etkilediğini ve sivil katıımla sosyal medyanın yakın ilişkisini ortaya koyduğunu ifade etmektedir. Hwang ve Kim (2015) sosyal hareketlere katılımın ve katıımın niyetinin; sosyal medyayı daha çok kullanan bireylerde daha yüksek olduğunu belirtmektedir. Bu durum sosyal medyanın çevrimiçi ve sanal ortamının, bireylerin gerçek yaşamlarında karşııık bulduğunu göstermektedir. Benzer şekilde, Türkiye'de Gezi Parkı olaylarında, ODTÜ yolu olaylarında ve 17 Aralık 2013 tarihli rüşvet ve yolsuzluk iddialarına dair İstanbul Cumhuriyet savcılı̆ınca başlatılan soruşma sonrasında, klasik medyanın yanında sosyal medya da önemli bir platform olarak kullanıldığı belirlenmiştir. Ayrıca 15 Temmuz 2016'da girişilen darbe girişimine karşı Cumhurbaşkanı Recep Tayyip Erdoğan'ın darbeye karşı halkı meydanlara çıkma çağrısı sosyal ve klasik medya üzerinden birlikte gerçekleşmiştir. Bütün bu sosyal ve siyasal fenomenlere dair toplumsal hareketler sosyal medyada yer edinmiş, hatta bazen yeni hareketin başlangıç ve esas platformunu oluşturmuştur. Dolayısıyla bu araştırmada da sosyal medyanın bu kapsamı büyük önem taşımaktadır.

Alanyazın incelendiğinde sosyal medya araçlarının genç öğrenciler tarafından toplumdaki diğer yaş gruplarına kıyasla daha yoğun kullanıldığı belirlenmiştir. Bu durumun araştırmacıları öğrencilerin sosyal sermaye kullanımlarına yönelttiği tespit edilmiştir. (Bkz; Ellison, Steinfield ve Lampe, 2007; Steinfield, Ellison ve Lampe, 2008; Ranieri, Manca ve Fini, 2012; Greenhow ve Burton, 2011; Haufer ve Aubert, 2013). Türkiye'deki araştırmalarda ise sosyal sermaye ve eğitim arasındaki ilişsinin incelendiği, sosyal sermayeye yönelik derleme türünde kuramsal çalışmaların gerçekleştirildiği ve sosyal sermayenin eğitim yönetimi bakış açısıyla ele alındığı belirlenmiştir (Ekinci, 2008; Güngör, 2011; Çelik ve Ekinci, 2012; Özdemir, 2007; Günkör, 2011; Yücel vd., 2013). Eğitim ve sosyal sermaye arasındaki ilişkiyi araştıran çalışmalarda ise öğrencilerin sosyal sermaye birikimlerinin, öğretmenlerin sosyal sermaye üzerindeki etkilerinin ve okul yöneticilerinin sosyal sermayeye yönelik liderlik davranışlarının öğretmen ya da yönetici görüşlerine göre değerlendirildiği görülmektedir. (Çankaya ve Çanakçı, 2011; Ekinci ve Karakuş, 2011; Çelik ve Ekinci, 2012). Bu durum, sosyal sermayeyle doğrudan ilişkili kişi ve gruplarla gerçekleştirilen çalışmalara gereksinim duyulduğunu göstermektedir. Daha detaylı incelendiğinde, bu gruplar arasından olan üniversite öğrencilerinin; sosyal sermayeyle ilişkili aktif demokratik vatandaşlık davranışları ile sosyal medya kullanımları arasındaki ilişkiyi ortaya çıkarmaya yönelik bir çalışmaya intiyaç duyulduğu görülmektedir.

\section{YÖNTEM}

Öğrencilerin sosyal sermaye birikimleri ile aktif demokratik vatandaşlık davranışları, demokrasinin işleyişindeki kurumlara duydukları güven ve sosyal medya kullanımları arasındaki ilişkilerin tespit edilmesinin amaçlandığı bu araştırma nitel araştırma yaklaşımlarından olgu bilim ile desenlemiştir. Olgu bilim araştırmalarında belli bir olguya, duruma ilişkin bireysel algıların ortaya çıkarılması ve yorumlanması amaçlanmaktadır (Yıldırım ve şimşek, 2011). Bu araştırmada betimleyici olgu bilim deseninden yararlanılmıştır. Çünkü bu araştırmada bireylerin belli belli bir duruma yönelik algılarının ortaya çıkarılması amaçlanmıştır.

\subsection{Katılımcılar}

Araştırma 2015-2016 Bahar döneminde çeşitli devlet üniversitelerinin sosyal bilim alanlarında öğrenim görmekte olan öğrencilerle gerçekleştirilmiştir. Araştırmanın çalışma grubu; amaçlı örnekleme yöntemlerinden ölçüt örnekleme yöntemi kullanılarak belirlenmiştir. Ölçütlerin belirlenmesi sürecinde öncelikle 12 devlet üniversitesinde öğrenim gören 2253 öğrenciden araştırmacılar tarafından geliştirilen nicel veri toplama araçlarıyla, nicel veriler toplanmıştır. Nicel veriler toplanırken öğrencilere görüşme yapmak için gönüllülük formu dağıtılmıştır. Gönüllülük 
formunu dolduran 46 öğrenci arasından ölçütleri sağlayan 11 öğrenci seçilmiştir. Bu ölçütler kapsamında ilk olarak siyasi, çevresel ve sosyal olaylara, hem sosyal medya üzerinden hem de fiziki olarak katılan gönüllü öğrencilerden maksimum çeşitliliğin sağlanmasına ve her bir üniversiteden ve bölümden eşit sayıda 3. veya 4. sınıf öğrencisinin seçilmesine dikkat edilmiştir. Sonraki aşamada öğrencilerle telefonla ön görüşmeler gerçekleştirilmiş ve aktif olarak çeşitli STK veya öğrenci grupları faaliyetlerine katılan ve dünya görüşleri birbirinden farklı olan öğrenciler belirlenmiştir. Ancak bu öğrencilerden bir tanesi özür beyan ederek görüşmeye katılmamıştır. Araştırmaya katılan öğrencilerin isimleri gerçek isimler değildir, araştırmada kod isimler kullanılmıştır. Öğrencilerin özellikleri Tablo 1'de verilmiştir.

Tablo1. Katılımcıların Özellikleri.

\begin{tabular}{llll}
\hline Öğrenci & En Çok Güven & Sosyal medyada geçirilen saat & Sosyal Medya Araçları \\
\hline Arda & Kolluk kuvvetleri & 240 dakika & Facebook, twitter, instagram \\
Buket & Kolluk kuvvetleri & 360 dakika & \\
Can & Kolluk Kuvvetleri & 300 dakika & Facebook, instagram \\
Demir & Kolluk kuvvetleri & 150 dakika & Facebook, instagram \\
Elif & Kolluk kuvvetleri & 150 dakika & Faceboook, instagram, swarm \\
Fulya & Kolluk kuvvetleri & 60 dakika & Facebook, instagram, twitter \\
Görkem & Güvenmiyor & 180 dakika & Twiter, facebook \\
Hilmi & Güvenmiyor & 100 dakika & Facebook, twitter \\
Kadir & Güvenmiyor & 60 dakika & Facebook, twitter instagram, \\
& & linkedin \\
Leyla & Güvenmiyor & 240 dakika & \\
Mehmet & Güvenmiyor & $150-200$ dakika & Facebook, twitter \\
\hline
\end{tabular}

Tablo 1'de görüldüğü gibi 11 öğrenciden 6'sı erkek, 5'i kadındır. Katılımcılardan 6' sı demokratik sistem kurumlarından kolluk kuvvetlerine güvendiğini ifade ederken 5'i hiçbir kuruma güvenmediğini ifade etmiştir. Ayrıca katılımcıların hemen hemen tamamı gün içerisinde facebook, instagram, twiter gibi sosyal medya araçlarında 60 dakika ve üstü zaman geçirdiklerini belirtmişlerdir.

\subsection{Veri Toplama Araçları}

Araştırma verilerin toplanmasında yarı yapılandııımış görüşme yöntemi kullanılmış, bu kapsamda araştırmacılar tarafından hazırlanan yarı yapılandırımış görüşme formundan yararlanılmıştır. Formun ilk bölümünde öğrencileri tanımaya yönelik kişisel bilgi soruları sorulmuştur. Daha sonra öğrencilerin kullandıkları bilgi kaynaklarını ve kullanım amaçlarını, demokratik sistem kurumlarına olan güvenlerini, sosyal sermaye birikimlerini ve demokratik vatandaşlık özelliklerini ortaya çıkarmaya yönelik olarak sorular sorulmuştur. Görüşmeler genellikle öğretim üyeleri odalarında gerçekleştirilmiştir. İinli olarak kayıt altına alınan görüşmeler yaklaşık 90-120 dakika arası sürmüştür

\subsection{Verilerin Analizi}

Nitel veriler, içerik analizine tabii tutulmuştur. İçerik analizinde öncelikle açık kodla başlanıp, merkezi koda ve temalara ulaşılmaya çalışılmıştır. Ancak, bazı konularda derinlemesine veri olmadığı için iyi bir kategori kavramsallaştırması gerçekleştirilememiştir. Bu yüzden, tümdengelim yaklaşımı benimsenmiştir. Bu analize temel oluşturan kategorilerin belirlenmesinde; teorik çerçeveden ve nicel verilerin analizinde ulaşılan boyutlardan yararlanılmıştır.

Nitel verilerin analizinde; inandırıcılık, aktarılabilirlik ve tutarlık ölçütlerinden yararlanılmıştır (Lincoln ve Guba, 1985'den akt: Yıldırım ve Şimşek, 2011). Bu araştırmada inandırıcılığın sağlanması için veri toplama araçlarının geliştirilmesinde ve verilerin analizinde uzman görüşü ve katılımcı teyidine başvurulmuştur. Araştırmanın yöntem bölümünde katılımcılar, veri toplama araçlarının hazırlanışı, veri toplama süreci ve verilerin analizi ayrıntılı olarak açıklanmıştır. Veri toplama aracı 
geliştirilirken önce soru havuzu araştırmacılar tarafından görünüş, kapsam ve teorik geçerlilik bakımlarından değerlendirilmiştir. Bu değerlendirmeler sonunda sorular yeniden formüle edilmiştir. İkinci aşamada bu taslak yarı yapılandırılmış görüşme formu alan uzmanlarına gönderilmiştir. Onların görüş bildirmesinden sonra sorular tekrar değerlendirilerek iki ayrı öğrenci ile pilot görüşmeler gerçekleştirilerek gerekli düzeltmeler yapılmıştır. Araştırmada aktarılabilirlik ölçütünü sağlamak için araştırma süreci ayrıntılı bir şekilde betimlenmiştir, bulgular bölümünde sık sık doğrudan alıntılara yer verilmiştir. Araştırmanın tutarlılı̆ını ve teyit edilebilirliğini sağlamak amacıyla veri toplama araçlarının hazırlanmasından analizine kadar tüm süreçler uzman görüşüne sunulmuştur. Uzmanlarla yapılan tartışmalar sonucunda tema ve kodlara son şekilleri verilmiştir. Ayrıca verilerin analizi için bilgisayar destekli nitel veri analizi programından yararlanılarak araştırmanın geçerliği ve güvenirliği artırımaya çalışımıştır.

\section{BULGULAR}

Araştırma kapsamında öğrencilerin sosyal sermaye birikimleri ile aktif demokratik vatandaşlık davranışları, demokrasinin işleyişindeki kurumlara duydukları güven ve sosyal medya kullanımları arasındaki ilişkilerin tespit edilmesi amacıyla öğrencilerle yarı yapılandırılmış görüşmeler gerçekleştirilmiştir. Elde edilen verilerin analizi sonucunda öğrencilerin sosyal sermaye ve sosyal medya: demokrasi ve vatandaşlık hakkındaki görüşleri 4 tema halinde ortaya çıkmıştır. Ortaya çıkan temalar Şekil 1' de sunulmuştur.

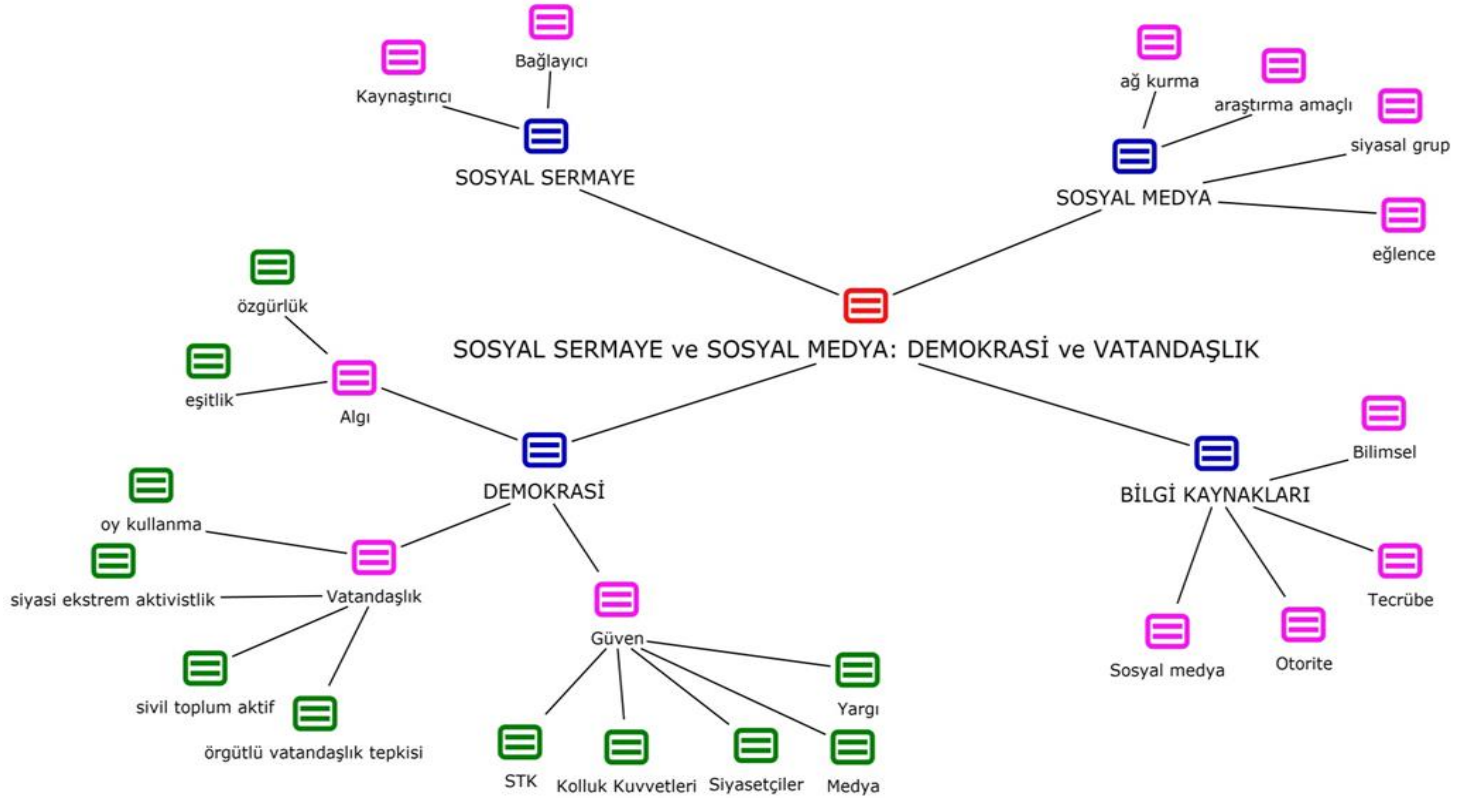

Şekil 1. Sosyal sermaye, sosyal medya ve demokrasi.

\subsection{Sosyal Sermaye}

Görüşmelerde öğrencilerin sosyal sermaye birikimlerine yönelik fazla derinlikli veri toplanamamıştır. Ancak, nicel verilerin analizinde kullanılmış olan teorik çerçevenin temaları kullanıldığında nitel verilerde aşağıdaki bulgulara ulaşılmıştır. Öğrencilerin sosyal sermaye birikimlerine yönelik bulgular Şekil 2'de sunulmuştur. 


\section{SOSYAL SERMAYE ve SOSYAL MEDYA: DEMOKRASİ ve VATANDAŞLIK}

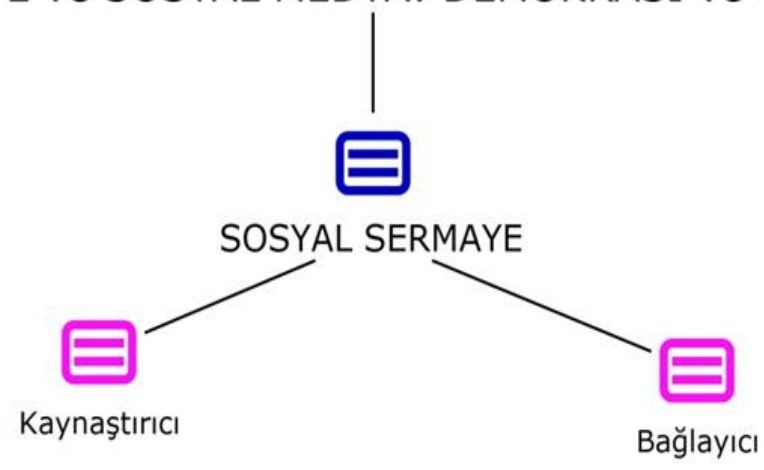

Şekil 2. Sosyal Sermaye

Şekilde görüldüğü gibi öğrencilerin sosyal sermaye birikimleri kaynaştırıcı sosyal sermaye ve bağlayıc sosyal sermaye olarak ortaya çıkmıştır. Kaynaştırıcı sosyal sermaye bireyin ailesi, yakın akrabası ve tanıdığı kişiler arasında internet aracılığıyla ve yüz yüze gerçekleşen ilişkileri kapsarken, bağlayıcı sosyal sermaye ise bireyin toplumun herhangi bir kesimine üye kişi ve gruplar ile oluşturduğu iş birliği ağları ve birlikte yürüttüğü gönüllü sosyal, siyasal ve çevresel faaliyetleri içeren yine yüz yüze ve internet aracılığıyla gerçekleşen ilişkileri kapsamaktadır. Öğrencilerin görüşleri incelendiğinde büyük bir bölümünün bağlayıcı sosyal sermayeye sahip olduğu ortaya çıkmıştır. Kaynaştırıı sosyal sermayeye yönelik olarak Elif 'Öncelikle böyle şeylerde arkadaşlık ilişkileri çok önemli. Biz mesela TEMA da bunu yakalayabileceğimiz için baya aktif olabildik arkadaşlık ilişkilerimiz çok iyi olabildiği için, rahat çalışabildik hem doğa için yararı bir şeyler yaptık hem de çevremizde genişledi' ifadesini kullanmıştır. Elif'in öncelikli olarak STK'larında çalışma nedeninin insanlar ve topluma faydalı olmak olduğunu ama aynı zamanda bu çalışmalar sayesinden çevresinin genişlediğini bunun kendisi için faydalı bir durum olduğunu düşündüğü görülmektedir. Bağlayıcı sosyal sermayeye yönelik olarak ta Elif 'Mesela ben TEMA üyesiyim bayağı oldu aktifliği falan ama mesela burada yaşayan bir Suriyeli aileye gidebiliriz para toplayabiliriz yardım edebiliriz ki böyle şeyler çok yaptık. Afganistanlı fakir bir aileye yardım ettik.' şeklinde çalışmalarını dile getirmiştir. Elif'in gönüllü olarak çalışma yaptığı STK doğa ve doğanın korunmasına yönelik çalışmalar yapan bir kuruluştur. Fakat Elif'in açıklamalarından belli amaç doğrultusunda çalışmalarına rağmen gerekli olduğu durumlarda başka gruplarla birleşerek yardım etkinliklerine katıldıkları görülmektedir. Bağlayıcı sosyal sermayenin oluşumunda internetin etkisine yönelik Kadir 'dediniz ki Eskişehir Batıkent' ten işte Bozüyük' e kadar olan otobanda çevre temizliği yapılacak ya da atıyorum gönüllü olarak bir okulun boyası yapılacak, tadilatı yapılacak şu gün şu yerde buluşup hep beraber oraya gideceğiz gibi etkinlik oluşturduğumuz zaman facebook'ta gönüllülük esası, kamuoyuna yararı olması yani bu örnekte insanlar beğeniyor, paylaşıyor.' ifadelerini kullanmıştır. Kadir' e göre insanların bir araya gelmesi ve topluma yararlı etkinlikler yapılmasında sosyal medyanın çok büyük etkisi bulunmaktadır. Farklı görüşlerdeki insanlar bile bu etkinliklerden sosyal medya aracılığılla haberi oluyor ve geniş kitlelerin katılımı sağlanıyor.

Demokratik toplumların dinamik yapılarının göstergesi olarak, toplumun üyesi bireylerin bağlayıcı sosyal sermaye birikimleri daha fazla önem arz etmektedir. Görüşülen üniversite öğrencilerinin hem bireysel hem de üyesi oldukları çeşitli topluluklar yoluyla ve başka topluluklarla birlikte çevre, eğitim, kadın ve siyaset alanında gönüllü faaliyetlere katılma gerekçeleri incelendiğinde "toplumun genel yararı için ellerinden geleni yapmanın sorumlulukları" olduğu bilinci sonucu çıkmaktadır. Bu, Putnam (1993)'ın yaşayan demokrasilerin belirgin özelliği olarak tarif ettiği durumdur. Yaşayan demokrasilerin başka bir özelliği ise, bireylerinin işleyen demokratik kurumlara dair duydukları güvenmeleri ve demokratik vatandaşlık davranışları sergilemeleridir. 


\subsection{Demokrasi}

Öğrencilerin demokrasiye yönelik görüşleri Şekil 3' te sunulmuştur.

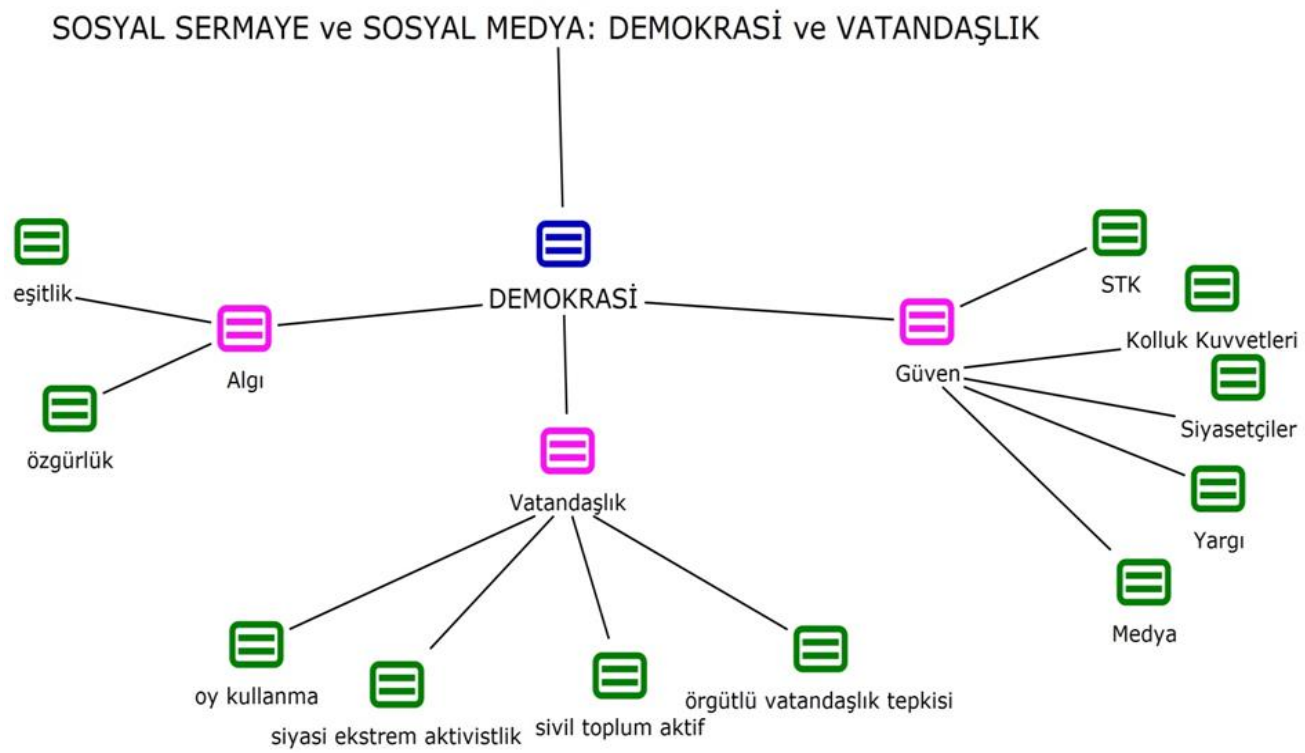

Şekil 3. Demokrasi.

Demokrasi Algısı: Şekilde görüldüğü gibi öğrencilerin demokrasiye yönelik düşünceleri demokrasiye yönelik algıları, sahip oldukları aktif vatandaşlık özellikleri ve demokratik sistem kurumlarına karşı duydukları güven olarak ortaya çıkmıştır. Bu bağlamda öğrenciler demokrasiyi özgürlük ve eşitlik olarak tanımlamışlardır. Hilmi demokrasiyi eşit haklara sahip olmayla ilişkilendirerek, Türkiye'de demokrasinin varlığıyla ilgili düşüncelerini 'Ülkemizde bir ayda yapılan eylemlerin sayısını öğrenebilir miyiz? Öğrenemedim. Çok fazla eylem var. Oradan şu sonucu çıkarttım. Demek ki Türkiye 'de çok daha fazla demokrasi yokmuş. Çünkü insanlar eylemleri demokrasinin gelmesi için yapıyor' şeklinde açıklamıştır. Hilmi'ye göre demokrasinin hakim olduğu bir ülkede bireyler eylem yapma gereği hissetmiyor, ülkemizde ise bireyler demokratik haklarına kavuşabilmek için eylemler yapıyor. Eşit haklarla ilgili görüşlerini ise 'Demokrasi bir ülkede herkesin eşit bir şekilde yaşadığı kendisini eşit bir şekilde ifade edebildiği bir ortamdır demokrasi. Bu eşitlikten kastım şudur: Yani herkesin eşit olması'. Ifadeleriyle açıklamıştır. Hilmi demokrasiyi ifade özgürlüğüyle ilişkilendirerek, demokrasinin varolabilmesi için ülkede yaşayan her bireyin eşit haklara sahip olması gerektiğini vurgulamıştır. Demokrasiyi eşitlik ve özgürlükle ilişkilendiren Fulya'da 'Eşit hak ve özgürlükler verilmesi demek. Yani demokrasi çocukluğumuzdan beri öğretilir. Vatandaşlık dersi ile tarih dersinde vesaire işte Sosyal bilgilerde Demokraside herkese eşit hak verilmesi gerekiyor. Ben ülkemde eşit hakka sahip değilim.' ifadelerini kullanarak yaşadığı ülkede, küçük yaşlardan itibaren formal ve informal ortamlarda demokrasinin öğretilmesine rağmen demokrasinin olmadığını yani bireylerin eşit hak ve özgürlüklere sahip olmadığını belirtmiştir.

Aktif Vatandaşlık: Öğrencilerin sahip oldukları aktif vatandaşlık davranışları oy kullanma, siyasi ekstrem vatandaşlık, örgütlü vatandaşlık tepkisi ve sivil toplum kuruluşlar aktif olarak sınıflandırılmıştır. Öğrencilerin büyük birçoğu düzenli olarak oy kullandığını ifade etmiştir. Buket düzenli oy kullanılmasının gerekliliğini 'ben zaten oy kullanmasam benim hiçbir şey söyleme hakkım yok. Oy kullandıktan sonra benim bir söz hakkımın olduğunu düşünüyorum. Ancak o zaman eleştiri yapabilirim.' sözleriyle açıklarken Demir de 'Oy vermezsen o zaman niye tepki gösteriyorsun. Oy senin vicdanında yargılayıp kime oy vermek istediğinin, kimi seçmek istediğinin en somut örneğidir, en iyi göstergesidir diyebilirim.' sözleriyle açıklamıştır. Buket ve Demir'in siyasi yönetimin yaptı̆̆ı uygulamalarda eleştiri yapabilmek için oy kullanmanın önemli olduğunu düşündüğü 
görülmektedir. Buket ve Demir'in aksine Elif, Fulya ve Görkem de sadece vatandaşlık görevleri olduğu için oy kullandığını yoksa herhangi bir parti ya da kişiye güvenmediklerini ifade etmişlerdir. Elif bu konudaki görüşlerini 'Oy verdiğimiz parti var mesela ama sırf hiç oy kullanmamış olmak için kullanıyorum. Tuttuğum güvendiğim ya da ne bileyim kesinlikle şunlar doğrudur iktidar da olmalı ya da evet bunlar doğru yapıyor dediğim bir parti yok açıkçası.' sözleriyle ifade etmiştir.

Siyasi ekstrem aktivistlik özellikleri izinsiz boykot, eylem gibi etkinlikleri kapsamaktadır. Bu davranışlara yönelik olarak birçok öğrenci yapılmasını doğal karşıladıklarını herkesin düşüncelerini istediği zaman istediği yerde dile getirebilmesi gerektiğini belirtmişlerdir. Fakat yalnızca Kadir, Leyla ve Mehmet izinsiz gösteri, eylem ve yürüyüşlere katıldığını Buket ise bunların olduğunu fakat katılmamasının sebebini 'Gerçekten uzun bir süredir, o Kızılay'a falan gidemedik. Çok fazla tepki göstermek istediler, protesto yapmak istediler ama korkularından kimse sokağa çıkamadı.' şeklinde ifade etmiştir. Mehmet ise siyasi ekstrem vatandaşlık davranışlarına yönelik olarak 'zaten protesto, gösteri vb. davranışlar izinli yapılması gereken şeyler değildir. Dolayısıyla birçok kere katıldım örneğin gezi eylemlerinde en önlerdeydim ve katılmayada devam edeceğim' söyleminde bulunmuştur.

Örgütlü vatandaşlık tepkilerinin gerekliliğine yönelik olarak Mehmet düşüncelerini 'Kitleler kendilerini ifade edebilmek adına toplumsal bir eylem içerisine girebilirler. Bu anayasada da sabittir. Anayasanın ilgili maddesi de bunu savunur., bu haklarını kullandığında insanların yaptırım gücü anlamında etkili bir rol oynayabileceği kanaatindeyim.' sözleriyle ifade etmiştir. Öğrencilerin sivil toplum kuruluşlarına katılımları incelendiğinde genellikle çevre ve yardımlaşmayla ilgili TEMA, Yeşilay, Kızılay, AFAD ve Çağdaş Yaşamı Destekleme Derneği gibi sivil toplum kuruluşlarına üye oldukları görülmüştür. Demir AFAD' a üyeliğiyle ilgili 'elimden geldiği kadar aktif olmaya çalışıyorum. Topluma faydalı olmak, insanlarla bir arada bulunmak ve en önemlisi gönül almak benim için en büyük hobimdir.' açıklamasını yapmıştır.

Genel olarak öğrencilerin aktif vatandaşlık özellikleri incelendiğinde birçoğunun düzenli oy kullandığı ama genellikle sadece vatandaşlık sorumlulukları olduğundan dolayı yaptıkları, siyasi parti ve siyaset yapanlara güvenmedikleri ayrıca bireylerin haklarını aramak için grev, eylem, protesto gibi davranışlarda bulunulmasının önemli olduğunu ama şu anda içinde bulundukları anti demokratik ortamdan dolayı bu davranışlarda bulunmaktan korktukları ve çevre ve yardım kuruluşlarıyla ilgili sivil toplum kuruluşlarında görev aldıkları görülmüştür.

Demokratik sistem kurumlarına güven: Öğrencilerin demokratik sistem kurumlarına (yargı, medya, siyasetçiler, kolluk kuvvetleri, sivil toplum kuruluşları) karşı duydukları güven incelendiğinde öğrencilerin tamamına yakını herhangi bir kuruma güvenmediğini belirtmişlerdir. Yargıya yani yargı çalışanları, mahkeme ve mahkeme kararlarına karşı duydukları güven incelendiğinde yalnızca Demir '.... Yargı hakkında benim görüşüm adil bir yargılama sistemi var diye düşünüyorum. Son zamanlardaki bu gereksiz ve yersiz tutuklamalar olduğu gibi bir görüş var. Türk adaleti bence olması gerektiği yerde. Ama bazen yanılgılar olabilir diye düşünmek gerekebilir.' sözleriyle güvendiğini belirtmiş ve bazen yargı kararlarınında da yanlışlar olabileceğini düşündüğünü söylemiştir. Can yargı sistemine olan güvensizliğiyle ilgili 'Türkiye'deki yargı sisteminin herhangi bir güvenilirliği yok, bu ordaki kişinin kendi ahlaki değerlerine bağı tamamen.' ifadesini kullanırken Hilmi de 'Türkiye'de yargı sistemine güvenmiyorum. Yargıdaki insanlara güveniyorum. Insandan insana değiştiğini düşünüyorum.' sözleriyle Can'ın da benzer görüşlere sahip olduğu ortaya çıkmıştır. Can ve Hilmi'nin görüşleri incelendiğinde ikisi de yargı sisteminin güvenilirliğinin olmamasının nedenini verilen kararların kişinin ahlaki değer ve çıkarlarına göre değişmesine bağladıkları görülmektedir ama onlara göre yargının doğru karar vermesi kişiden kişiye değişen bir olay değildir, hukuk kuralları kişiye ya da olaya göre değiş̧en yargılar değildir. Araştırma sonucunda öğrencilerin yargıya güvenmemelerinin ana sebebi yargının bağımsız olmamasından kaynaklı olduğu ortaya çıkmışır. Buket bu konudaki görüşlerini 'bu güç otorite var ya aslında en büyük güç onlarda olması gerekiyor. Sonuçta siyasetçilerin de üstünde olmaları gerekiyor. Yasalar onların da uyması gereken şeyler var. O yüzden hukukun ondan daha üstün olması gerekiyor.' sözleriyle ifade etmiştir. Buket'e göre ülkedeki en büyük güç, otorite adalet sistemi olması gerektiği halde günümüzde siyasetçilerin yargı sistemine karşı büyük bir üstünlüğü bulunmaktadır. Buket gibi yargının siyasetin etkisinde kaldığını düşünen Kadir de 'Bence 
bu kadar etkisi olmaması lazım. Kendi yandaşları ne zaman bir suç işliyor, kanun neyse onun işlemesi gerekirken hemen belli değişikliklere gidiliyor. Bu da ister istemez insanlarda bir güvensizlik yaratıyor.' ifadesini kullanmıştır. Kadir'e göre yargı kararları kişiye ya da olaya göre değişmemelidir ama yaşadığı ülkede siyasi organların yargının üzerinde etkisi bulunmaktadır. Hilmi de siyasetin yargı üzerindeki baskısına yönelik görüşlerini 'Bizim Türkiye'de yargı sistemimiz bir şekilde siyasal iktidara bağlı. Atama yoluyla ... Sen bir muhalif bir insansın bu ülkede. Kadın, işte solcu, alevi atıyorum Roman bir etnik fark etmez ya da bir tane ezilen bir insansın yâda muhalifsin. Yargının orada eșit davranması için önce bu insanların hepsinin bağımsız olması lazım. Bağımsız mahkemelerin olması lazım. Şimdi HSYK dediğimiz kurum Yargıtay dediğimiz Danıştay dediğimiz kurum hepsinin atama yöntemi şöyle olduğunu öğrendim şu anki hükümet tarafından atanıyor' biçiminde ifade etmiştir. Öğrencilerin yargıya güvenle ilgili düşünceleri incelendiğinde yargı sisteminde yer alan hakim, savcı vb. kişiler siyasi iktidarlarla olan ilişkilerinden dolayı bağımsız olamamaktadır, dolayısıyla verdikleri kararlara da güven duyulmamaktadır.

Öğrencilerin siyasetçilere karşı duydukları güven incelendiğinde yalnızca Arda siyasetçilere güvendiğini 'Bir kere toplumda diyelim yöneticiyse; o toplumun ihtiyaçlarını göze alıyor. Hani toplumda düzeni sağlamaya çalışıyor. O yüzden toplumu korumaya güveni sağlamaya çalışır.' biçiminde ifade etmiştir. Siyasetçilere güvenmediğini ifade eden öğrencilerin görüşleri incelendiğinde ise güvenmemelerinin iki ana sebebi olduğu ortaya çıkmıştır: Bunlardan birincisi siyasetçileri tutarsız bulmalarıdır. Siyasetçilere güvenmeme sebebinin tutarsızlıkla ilişkilendiren Mehmet düşüncelerini 'Parlamentoya girmeden önce çok farklı olan bir bireyin parlamentoya girdikten sonraki tutum, davranışlarının son derece değişik olması. Bu güveni etkiliyor. O insanlar bir takım yetki ve görevler aldıklarında sorumluluklar aldıklarında bambaşka birileri olabiliyor.' şeklinde ifade ederken Leyla da 'Siyasete atıldıktan sonra tamamen siyasetin içinde kalmak, yükselmek hedefleri. O yüzden bugün $A$ görüşünü savunan birisi yarın $B$ görüşünü doğduğundan beri B görüşündeymiş gibi savunuyor.' biçiminde ifade etmiştir. Mehmet ve Leyla ya göre siyasetle ilgilenen insanların seçilmeden önceki tutum ve davranışları ile belli yerlere geldikten sonraki tutum ve davranışları hatta içinde bulundukları siyasi görüşleri bile değişmektedir, bu da siyasetçilere duyulan güveni olumsuz etkilemektedir. Araştırmada ortaya çıkan siyasetçilere güven duyulmamasının diğer sebebi ise kişisel çıkarları gözetmedir. Bu konudaki görüşlerini Can 'Siyasetçiler için de koltuk hırsı. Koltuğun olunca gücün oluyor, gücün olunca insanlar size firsatlar veriyorlar. Para kazanabiliyorsun. Yani daha çok para üstüne dönen bir dolap bence' biçiminde ifade ederken, Demir de 'şu anki dönemde siyasetçiler biraz daha rant sağlama peşinde. Koltuk sevdasında. Ama hani siyasetçilere tam güvenim yok. Eminim yüz kişiye sorsanız, yüz kişiden 85-90'ı güvenim yok cevabını verecektir.' Biçiminde ifade etmiştir. Can ve Demir'in görüşleri incelendiğinde siyasetçilerin seçildikten sonra çoğunlukla maddiyat kaynaklı olarak halkın öncelliğinden ziyade kendi kişisel çıkarlarını düşündükleri görülmektedir. Bu durumda siyasetçilere güven duyulmamasına sebep olmaktadır.

Öğrencilerin medya ve medya organlarına duydukları güven incelendiğinde öğrencilerin tamamının medya kaynaklarına güvenmedikleri ortaya çıkmıştır. Can medya organlarına ve yayınlarına duyduğu güvenle ilgili 'Medyaya güvenmiyorum. Çünkü $O$ an iktidarda bulunan kişilerin medyanın çalışma durumuyla ilgili kesin durdurma veya devam etmelerine dair kesin bir şeyleri güçleri var ellerinde. Medya da buna yönelik davranışlarda bulunuyor'. Ifadelerini kullanarak medyaya güvenmediğini çünkü, siyasetin medyanın üzerinden büyük bir etkisi olduğunu ve özgür olmadığını dolayısıyla yayılan korku kültüründen yanlı yayınlar yapıldığını belirtmiştir. Mehmet ise medyaya güvenmeme sebebini 'Her gazetenin, gazetecilerin, grubun kendi doğruları var. O yönde yayın yapıyor.' sözleriyle ifade ederek Türkiye'de medyanın durumuyla ilgili 'Medya hiçbir zaman özgür olmadı ve olmayacak da. Olmasını ümit ederim ama Türkiye'de yaşıyorsanız...Yani açık konuşalım şimdi iktidar ve sermaye eksenindeki basın hep o eksen arasında kalır hocam. O eksen arasında gider gelir.' açıklamalarını yapmıştır. Can' da Türkiye' deki yayın organlarının yanlı yayın yapmasının nedenini 'Nedeni para ve güç. Başımız belaya girmesin diye. Biz ekmeğimizi götürelim, yatımızda gezelim tarzı bir olay biraz daha' biçiminde ifade ederek medya organlarının sahiplerinin maddi çıkar ve dolayısıyla güç sağlamak istemesiyle ilişkilendirmiştir. 
Öğrencilerin kolluk kuvvetlerine yani asker, polis vb. ülkenin güvenliğini sağlayan kurumlara duyulan güven incelendiğinde, genel olarak güvendikleri ortaya çıkmıştır. Demir kolluk kuvvetleri duyduğu güvene yönelik düşüncelerini 'Asker ve polis üzerlerine düşenleri haddiyle yapıyor. Zor bir iş yapıyorlar. Biz burada rahat oturuyorsak gece rahat uyuyorsak, gece 2-4 nöbeti tutan asker sayesinde, evine gidemeyen sürekli karakolda sabahlayan sürekli operasyona giden, acaba bugün de ben gitsem kaç insan rahat uyuyabilecek diyen insanlar, polisler sayesindedir. Onlara güvenimiz tam yani.' sözleriyle açıklarken Elif'te benzer görüşleri ifade etmiştir. Can ise kolluk kuvvetlerine genel olarak güvendiğini ifade etmesine rağmen 'Askeriye veya polis teşkilatının bir şekilde halkı tehlikeye atmak için bir şeyler yapmak gibi bir amacının olmadığına inanıyorum. Ama emir eri hepsi sonuçta bu emir komuta zinciriyle dönen bir sistem. Ve sen üstünden gelen emirlere uymak zorundasın. O yüzden çok da emin de olamıyorum. Orda da kişisel şeyler dönebilecek bir yer.' biçiminde eklemeler yapmıştır. Can gibi emir komuta zincirinin yaratabileceği olumsuzluğa dikkati çeken Görkem 'Bir taraf emir eri iken diğer taraf emir almak durumundadır ve nihayetinde tamamen görüşü temsil etmek zorunda değildir. İşi gereği yapıyordur belki bunu çünkü bunu biliyoruz. Onların düşüncesiyle o kararları alan insanların düşüncesi çok farkı. Mağduriyet durumu açııından dışında tutmam gerekiyor çünkü bazı politikaların kurbanları diyebilirim. Ben onları kurban olarak görüyorum dolayısıyla güven konusunda kafam karışık' ifadelerini kullanarak aslında emir alan asker ve polislere güven duyduğunu ama emir veren üst kademedeki rütbeli insanların siyasi baskılardan dolayı yanlış davranışlarda bulunabileceğini, bununda kolluk kuvvetlerine duyduğunu güveni azalttığını belirtmiştir. Siyasetin kolluk kuvvetlerinin üzerindeki etkisine dikkati çeken Hilmi 'şiddeti kullanan bir kuruma güvenmiyorum. Şiddeti kimin nasıl kullanacağını, nasıl bir şekilde hangi ölçüde kullanacağını kim tarafından belirleneceğini bir kanıtı ya da bir ölçüsü yok. Şiddet araçlarının belli bir grup tarafından kullanılmasının doğru olduğunu düşünmüyorum. Hele ki bunun Siyasal iktidarın kullandığını düşünüyorum' diyerek Türkiye'de yakın zamanda yaşanan orantısız güç kullanıma yönelik 'Ama Türkiye gibi bir ülkede çok böyle baskının olduğu ve sürekli bir siyasal iktidarın onu kullanmasını yaptığı baskıyla öyle olduğunu düşünüyorum. Çünkü Gezi olaylarında gördüğ̈̈nüz gibi çeşitli ölümlerin sebebi polisin kullanmış olduğu şiddet oldu.' biçiminde örnekler vermiştir. Hilmi'nin kolluk kuvvetlerine duyduğu güvenle ilgili görüşleri incelendiğinde yaşadığı ülkede kolluk kuvvetlerinin siyasetin etkisinde kalarak orantısız güç kullanılmasından kaynaklı olarak güven duymadığı görülmektedir. Genel olarak öğrencilerin demokratik kurumlara duydukları güven incelendiğinde en çok kolluk kuvvetlerine güvendikleri ortaya çıkmıştır fakat araştırma 15 Temmuz darbe girişiminden önce gerçekleştirilmiştir. Kamuoyunda yapılan araştırmalarda (AveG,2016), 12 Temmuz darbe girişiminden sonra askere duyulan güvenin azaldığı sonucu ortaya çıkmıştır. Dolayısıyla bu araştırmanın bu boyutuyla ilgili yapılan görüşmeler tekrar edilir ise farklı sonuçların çıkması beklenebilir.

3.3. Bilgi Kaynakları: Bireylerin günlük yaşamda karşılaştıkları problemleri çözmede farklı bilgi kaynaklarını kullandıkları görülmektedir. Buna göre görüşme yapılan öğrencilerin başvurdukları bilgi kaynakları Şekil 4'te sunulmuştur.

SOSYAL SERMAYE ve SOSYAL MEDYA: DEMOKRASİ ve VATANDAŞLIK

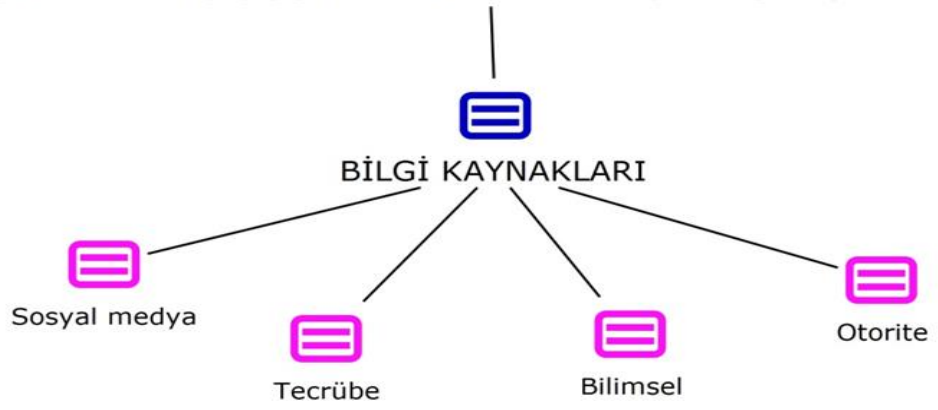

Şekil 4. Bilgi Kaynakları 
Şekilde görüldüğü gibi bireyler günlük hayatlarında karşılaştıkları sorunları çözerken başvurdukları bilgi kaynakları sosyal medya, otorite, kendi yaşam tecrübeleri ve bilimsel kaynaklar olarak ortaya çıkmıştır. Görüşme yapılan öğrencilerden birçoğu bilgi kaynağı olarak çabuk ve ulaşılabilir olmasından dolayı sosyal medyayı kullandığını ama çok da güvenilir bulmadığını, teyit etme intiyacı hissettiğini ifade etmiştir. Bu görüşü benimseyen Buket düşüncelerini 'Bende ne bileyim bu bilgiyi şu an teknoloji çağındayız ve genelde oraya yöneliyorum şu an çünkü elimin altında en kolay ulaşabildiğim şey. Ama her zaman doğru bilgi olmuyor tabi' şeklinde açıklamıştır.

Bilgi kaynağı olarak bilimsel yolları tercih eden öğrencilerden, öğrenci Mehmet öncelikle ne tür bir bilgi kaynağını seçerken önce ne tür bir bilgiye ihtiyacı olduğunu belirlediğini 'Öncelikle bilgi edinmem gereken noktayı belirlerim. Yani bu nedir? Sosyal bilimler alanında mı yoksa farklı analitik birtakım düşünce bilimleri arasında mı sınıflandırııım' sözleriyle ifade ederek daha sonra bilimsel yollarla bilgiyi elde ettiğini ‘örneğin tarihsel bir konu üzerinde bilgi edinmek istedim, bu bilgiye ihtiyacım var, buna yönelik arşiv ve kaynak taraması yapmak için kütüphane ve birincil kaynakları kullanırım' şeklinde açıklamıştır. Bilgi kaynağı olarak bilimsel yolları tercih eden öğrenciler bilimsel bilgi kaynakları olarak fiziki ve çevrimiçi kütüphaneleri, hem Türk hem de yabancı kaynakları kullandıkları görülmektedir.

Buna göre Arda herhangi bir problem yaşadığında çözüme ulaşabilmek için otoriteye başvurduğunu 'Dersle ilgiliyse hocaya başvurabiliyorum. Dersin hocasına veya günlük hayatta bir problem yaşadım mesela ailemden birisine danışabilirim.' sözleriyle ifade etmiştir. Mehmet ise başvurduğu kaynağı otorite boyutuyla ilişkilendirerek görüşlerini 'Siyaset bilimi üzerinden bir terminolojik bir bilgiye ihtiyacım var, bunu teyit etmem gerekiyor. Bu bilgiye ilişkin olarak bu konuyla ilgili alanında uzman birisine başvurup bunu teyit ediyorum.' şeklinde açıklamıştır. Bilgi kaynağı olarak otoriteyi tercih eden öğrencilerin otorite olarak alan uzmanlarını, danışman öğretim elemanlarını ve aile büyüklerini tercih ettikleri görülmektedir. Yalnızca bir öğrenci ise yaşadığı sorunların çözümünde geçmiş yaşantılarındaki tecrübelerinden yararlandığını belirtmiştir.

Sosyal medya üzerine öğrencilerle yapılan görüşmelerde sosyal medyada bazı sahte isimler kullanılarak açılan hesaplar olduğu ortaya çıkmışır. Öğrenciler sahte hesap açılmasının sebeplerini özgüven eksikliği ve toplum baskısı olarak görüş bildirmiştir. Sahte hesap açılmasının sebebini özgüven eksikliğiyle ilişkilendiren Hilmi bu konudaki görüşlerini ‘özgüveni düşük olan bireylerin bu şekilde toplumda yer edinebilme çabası olarak çıktığını söyleyebilirim' şeklinde dile getirerek 'Hoşuna giden bir kız vardır. Ama kendinin öğrenilmesini istemiyorsundur. Korkuyorsundur. O yüzden fake hesap açarsın. Kızla konuşmak istersin, mesaj atarsın. Kız kabul ederse gerçek ismini söylersin. Etmezse, söylemezsin böyle de bir amacı var.' örneğini vermiştir. Mehmet ise bu durumu 'özgüveni düşük olan bireylerin bu şekilde toplumda yer edinebilme çabası olarak çıktığını söyleyebilirim' sözleriyle açıklamıştır. Toplum baskısından dolayı sahte hesaplar açıldığını belirten Leyla bu konudaki yaşantısını 'bir arkadaşım vardı gerçekten bulunduğu mahalleden dolayı bir baskı altındaydı. Kesinlikle mahallede öyle bir giyinme tarzı yoktu. Başka bir şehirde üniversite okuduğu zaman öyle giyinebiliyordu ama öbür türlü giyinemiyordu... Instagram hesabı yabancı bir isimdi. Yani o ismi bilmeden gidişte bakamazsın. Farklı bir isim yazarak fotoğraflarını koyuyor fake değil ama ismi fake gibi. Ailesi ulaşmasın mahallesindeki insanlar ulaşmasını diye Bu da aslında ciddi bir şey. Şu mahalle baskısı, toplum baskısı dediğimiz şey gerçekten önemli yani" şeklinde açıklamıştır. 


\subsection{Sosyal Medya}

Öğrencilerin sosyal medyayı kullanma amaçları Şekil 4' te sunulmuştur.

\section{三 \\ SOSYAL SERMAYE ve SOSYAL MEDYA: DEMOKRASİ ve VATANDAŞLIK}

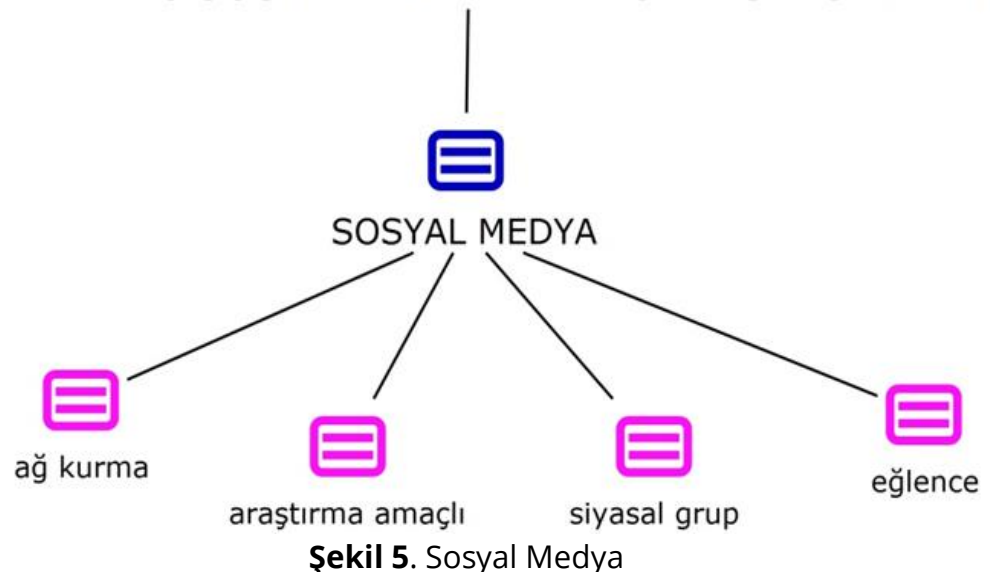

Şekilde görüldüğü gibi öğrencilerin sosyal medyayı ağ kurma, araştırma, siyasal grupla etkileşim ve eğlence amaçıı kullandıkları ortaya çıkmıştır. Öğrencilerle yapılan görüşmeler sonucunda hemen hemen hepsinin facebook, instagram, twiter vb. gibi sosyal medya hesapları olduğu, aktif olarak kullandıkları ve tek bir amaçtan ziyade sosyal medya aracılığıyla araştırma, eğlence ve network kurma gibi birçok amacı gerçekleştirmek için kullandıkları ortaya çıkmıştır. Sosyal medyayı çok aktif olarak kullandığını ifade eden Demir görüşlerini 'artık, internet deyince akla facebook ve instagram geliyor. Toplumsal ve sosyal olarak da dediğim gibi bilgiyi paylaşma, aktarma ve görüş analizi yapabilmek için. Şimdi ben Osmangazi üniversitesi genç tema kulübündeyim. Facebook grubumuz olmasa ben herkesi arayıp tek tek ulaşamam, ona vaktim yetmez. Instagramda da grubumuz var mesela o da olmasa fotoğraf paylaşamaz' biçiminde açıklarken Leyla'da 'bir grup açtınız diyelim hayvan haklarına şurada sahip çıkıyoruz mesela diye grup etkinlik yaptığınız zaman. Bunları arkadaşlarına, arkadaşlarının arkadaşlarına bunlar böyle daha çok yayılır ve daha kamuoyu oluşturma şansınız olur.' ifadelerini kullanmıştır. Demir ve Leyla'nın görüşleri incelendiğinde ikisi de benzer görüşleri, benzer ilgi alanları hobileri olan insanların sosyal medya aracılığıyla bir araya gelmesinin kolaylaştığını, ayrıca bireysel tepki verilmesinin yerine bazı olaylar karşısında sosyal medya aracılığıyla insanların bir araya geldiği daha toplumsal tepkilerin kolaylıkla verilebildiği böylece daha etkili olduğunu vurguladıkları görülmektedir.

Sosyal medyayı araştırma amaçılı kullanan Görkem '... az önce bir olay mı oldu, bir şey mi oldu, en canlı takipçisi sosyal medya. Twitter özellikle daha revaçta bu tür konularda. Çünkü insanların oradan bir haber göndermesi, şey yapması daha basit oluyor anlık olarak. Öğrenmek istediğim her türlü bilgiyi en çabuk oradan öğreniyorum' ifadesini kullanırken Kadir de 'Basılı kaynaklar, yani gazeteler olur dergiler olur sosyal medyayı aktif olarak kullanıyorlar. Onlar da bu işin içine girdiler. Hani bu düzeyde bir bilgiye öğrenmek içinde, edinmek içinde sosyal medyayı kullanıyorum.' ifadelerini kullanmıştır. Öğrencilerin görüşleri incelendiğinde en hızlı ve en kolay haber alma imkânı bulabildikleri için sosyal medyayı araştırma amaçlı kullandıkları ortaya çıkmıştır.

Sosyal medya hesaplarını aktif olarak kullanan Elif kullanım amacını 'çok güncel bilgiler ya da siyasi bilgileri takip etmek için.' şeklinde açıklayıp 'Çünkü sosyal medyada daha hızlı bir erişim olduğu için hemen anında bilgiler paylaşılıyor, anında yayılıyor anında daha çok bilgi edinebiliyorsun. Hani uzun bir araştırma süreci gerektirmeyen bir şey elinin altında bilgisayar olsun, telefonu olsun erişim daha kolay ve daha çok bilgiye ulaşıyorsun. Özellikle siyasi konularda böyle.' sözleriyle neden öncelikli olarak sosyal medya kullandığını gerekçeleriyle ifade etmiştir. Buket ise sahip olduğu siyasi görüşe 
mensup politikacıları sosyal medya hesabından takip ettiğini 'şu an siyasi kişilerin bile facebook' ları var onları takip edince en net, doğru bilgiler oradan çıkıyor yani karşıma.' sözleriyle ifade ederek ona göre en doğru bilgi kaynağının onların sosyal medya hesapları olduğunu belirtmiştir. Öğrencilerin sosyal medyayı network kurma, siyasal grup kurma ve araştırma yapmak dışında eğlenmek, vakit geçirmek amacıyla kullandığı ortaya çıkmıştır.

Kadir sosyal medyayı kullanım amacını 'bu vine dediğimiz olay var, şimdi artık bütün biliyorsunuz, espriler, şeyler önceden bir televizyonda mesela bir Recep ivedik vardı, onu izlerdik. Bütün herkes o esprileri yapardı ama şimdi herkeste şu algı var; herkes Facebook kullanıyor, bundan haberdardır mesela orda bir espri, bir söz geçiyor, tutup bir arkadaş ortamında biri size yaptığı zaman sizin bildiğinizi varsayıyor artık ister istemez. Hani gittiğiniz bir ortamda bilgili, kültürlü olmanız gerekir. Yapay kültürü bu şekilde edinmeniz gerekir.' biçiminde ifade ederek sosyal medyayı eğlence ve toplum tarafından kabul edilmek için kullandığını belirtmiştir. Ayrıca sosyal medyayı eğlence amaçlı kullandığını belirten Arda ve Leyla düşüncelerini 'Instagramı kendi anılarımı paylaşmak için.' şeklinde ifade etmiştir. Genel olarak öğrencilerin sosyal medyayı kullanım amaçları incelendiğinde benzer ilgi alanları olan insanlarla tanışıp ortak paylaşımlarda bulunmak, hızlı ve ulaşılabilir olduğu için araştırma yapmak, sahip oldukları siyasi görüşe mensup siyasetçilerle birlikte siyasi gündemi de takip etmek ve eğlence amaçlı fotoğraf, video ve benzeri paylaşımlarda bulunmak aynı zamanda kendi benzetmeleriyle yapay kültürden uzak kalmamak için kullandıkları görülmektedir.

\section{SONUÇ, TARTIŞMA ve ÖNERILER}

Üniversite öğrencilerinin sosyal sermaye birikimleri ile aktif demokratik vatandaşlık davranışları, demokrasinin işleyişindeki kurumlara duydukları güven ve sosyal medya kullanımları arasındaki ilişkilerin ortaya çıkarılmasının amaçlandığı bu araştırmada elde edilen sonuçlar sosyal sermaye, demokrasi, bilgi kaynakları ve sosyal medya olarak ortaya çıkmıştır. Araştırmada öğrencilerin sosyal sermaye birikimleri kaynaştırıcı sosyal sermaye ve bağlayıcı sosyal sermaye olarak ortaya çıkmıştır. Öğrencilerin görüşleri incelendiğinde büyük bir bölümünün bağlayıcı sosyal sermayeye sahip olduğu ortaya çıkmıştır. Sosyal sermayenin toplumsal yapıyı koruyan, sivil ve gruplar arası işbirliği yoluyla sorunları ortadan kaldırımasına katkı sağlayan boyut bağlayıcı sosyal sermayedir (Van Deth, 2010).

Öğrencilerin demokrasiye yönelik görüşleri incelendiğinde demokrasiye yönelik algıları, sahip oldukları aktif vatandaşlık özellikleri ve demokratik sistem kurumlarına karşı duydukları güven olarak ortaya çıkmıştır. Öğrenciler demokrasiyi eşitlik ve özgürlük kavramlarılla ilişkilendirmiştir.

Öğrencilerin sahip oldukları aktif vatandaşık davranışları oy kullanma, siyasi ekstrem vatandaşlık, örgütlü vatandaşlık tepkisi ve sivil toplum kuruluşlar aktif olarak sınıflandırılmıştır. Yine araştırma sonuçlarına göre öğrencilerin demokratik sistem kurumlarından kolluk kuvvetlerine güvendiği ortaya çıkmıştır. Bunu sebebi de ülke güvenliğinin teminatının onlar olduğu algısı ve aynı zamanda "Cumhuriyet'in kazanımları" olarak kavramsallaştırılan "yaşam biçiminin" koruyucusu olarak görmeleridir. Bu beklenen bir sonuçtur çünkü sivil bir yönetim tarzı olan temsili demokraside, ilginç bir şekilde kolluk güçlerinin demokratik sistemin koruyucusu olarak görülmesi ihtimali oldukça güçlüdür. Bu durum, Türkiye'nin imparatorluktan cumhuriyet geçiş tecrübesinin sonucu olarak yaşanan tecrübelerinin bakiyesi olsa gerektir. Ayrıca, Türkiye'nin yıllardır yürüttüğü ve son yıllarda yoğunluğu ve çeşidi artan terörle mücadelenin de bunda etkisi olduğu söylenebilir. Fakat bu verilerin Temmuz 2016 darbe girişiminde önce toplanmış olduğu için özellikle kolluk kuvvetlerine güven duygusunda bir farklılaşmanın olması beklenir. Bununla birlikte, son aylarda yapılan bazı araştırmalar hala silahlı kuvvetlerinin güvenilen bir kurum olduğunu göstermektedir (A ve $G, 2016$ ). Yargıya olan güvensizliğin sebebi ise son dönemde yaygın bir şekilde ülke gündeminde yer alan yargının siyasallaşması ve kutuplaşma tartışmalarından kaynaklanıyor olabileceği düşünülmektedir. Özellikle darbe girişimden sonra yaşanan süreç bu kutuplaşmanın ne boyutlara çıkmış olduğunu göstermektedir. Görüşmelerde öğrencilerin vurgulamış oldukları en önemli husus, yargının siyasallaşması ve aynı zamanda zengin ve güçlü kişilerin adalette bile istediklerini elde 
etmiş olduklarıdır. Siyaset, (belli bir ölçüde de medya ) demokratik işleyiş içerisinde halkın sesi olarak tanımlanabilir fakat bu birbirinden çok farklı siyasi ve ideolojik görüşe mensup olan üniversite öğrencileri, siyaset ve ideolojiler üstü bir mutabakatla kendi iradelerini ve seslerini temsil etmesi gereken kuruma neredeyse hiç güvenmemektedir.

$\mathrm{Bu}$ araştırmanın benzer nitelikteki diğer araştırmalardan ayrılan en önemli yanı araştırmaya öğrencilerin bilgi kaynaklarının neler olduğunu araştırılması boyutunu da katmış olmasıdır. Bu araştırmada öğrencilerin günlük hayatlarında karşılaştıkları sorunları çözerken başvurdukları bilgi kaynakları sosyal medya, otorite, kendi yaşam tecrübeleri ve bilimsel kaynaklar olarak ortaya çıkmıştır. Öğrencilerin birçoğunun bilgi kaynağı olarak çabuk ve ulaşılabilir olmasından dolayı sosyal medyayı kullandığı ama çok da güvenilir bulmadığı ortaya çıkmıştır. Bacanlı (2015) ise bireyin başvurduğu bilgi kaynaklarının otorite, gelenek, tecrübe ve bilimsel kaynakları olarak ifade etmiştir. Bilimsel bilgi büyük oranda güvenilir olmakla birlikte, ulaşılması zor bir bilgi türüdür. Otorite ve tecrübe ise kullanışlılık, ulaşım kolaylığı ve güvenirlik açısından üniversite öğrencileri tarafından tercih edilebilecek dengeli bir bilgi kaynağı olarak görülüyor olduğu şeklinde yorumlanabilir. Bütün bu sonuçlardan hareketle sosyal medyanın, sözü edilen toplumsal olaylarda üniversite öğrencilerinin bilgi kaynağı olarak büyük bir etkiye sahip olmadığını söylemek mümkündür. Kuvvetle muhtemeldir ki, bu olaylarda sosyal medyayı etkin kullanan kişiler, burada paylaşılan bilgilerin güvenirliğine üniversite öğrencilerinin genel ortalamasından daha fazla güvenen, sosyolojik olarak dezavantajlı sosyoekonomik seviyedeki aile yapılarından gelen ve ideolojik olarak statükoya karşı çıkmaya yatkın olanlardır. Sosyal medya, gençliğin tamamını harekete geçirme bakımından aynı etki gücüne sahip değildir. Ancak potansiyel olarak yatkın olanlar sosyal medyayı etkin kullanıp etkin örgütlenebilmektedirler.

Öğrencilerin sergilemiş oldukları çeşitli düzeydeki demokratik vatandaşlık davranışlarında başvurdukları bilgi kaynakları ve bu kaynaklar arasında sosyal medyanın yerini bilmek son derece önemlidir. Birincil bilgi kaynağı olarak tercih etmemelerine rağmen Arap baharı ile başlayan ve dünyanın değişik bölgelerinde de görülen çeşitli halk hareketlerinde sosyal medya etkin bir şekilde kullanılmıştır (Howard et all, 2011; Kassim, 2012: Wolfsfeld, Segev ve Sheafer, 2013, Reed, 2016). Türkiye'de de benzer rolü sosyal medya üstlenmiştir (Korkmaz, 2014; KONDA, 2014). Üniversite öğrencileri de bu olaylara katılmış ve sosyal medyayı da bu katılımda platform olarak kullanmışlardı.

Sosyal medya kullanım amaçlarına yönelik en önemli bulgu ise öğrencilerin sosyal medyayı en çok araştırma amaçlı kullandıklarını ifade etmeleridir. Diğer en çok kullanım amacı ise eğlence ve vakit geçirme amaçlı kullanımdır. Çalışma grubundaki insanların üniversite öğrencilerinden oluştuğu düşünüldüğünde araştırma yapmak amacına yönelik kullanım şaşırtıcı olmasa gerektir. Öğrencilerin araştırmadan kastettikleri arasında ders konuları ve ödevler hakkında bilgi edinmek ve çeşitli sosyal konuların iç yüzü hakkında bağımsız, tarafsız ve çok bakışlı haber edinmek olduğu da gözükmektedir. Aslında kast edilen şey sosyal medya üzerinde bilimsel kaynak ve kişilere erişim yoluyla bilimsel bilgiye ulaşmak değildir. Bu yorumla birlikte, öğrencilerin sosyal medyayı vakit geçirme amaçlı kullanım ortalamaları bulgusu birlikte değerlendirilince toplum sosyal medyanın gençler arasında zaman öldürmek için kullanıldığı algısı ile örtüşen bir durum vardır. Ayrıca öğrencilerle yapılan görüşmelerde de siyasal alanda aktif olan öğrencilerin sosyal medyayı bağlı bulundukları grupların dışındaki kişi ve gruplarla bağlantı kurmada ve örgütlenmede etkin bir platform olarak kullandıklarına dair bulgulara ulaşıımıştır. Bu durum özellikle güncel siyasal ve toplumsal konulardan haberdar olup, o konulara dair yapılan gösteri, protesto ve imza kampanyası gibi etkinliklere katılım konusunda olduğu öğrenci ifadelerinden anlaşılmaktadır.

Araştırma sonuçları incelendiğinde öğrencilerin sosyal medyayı, eğlence, vakit geçirme, sosyalleşme gibi sebeplerle kullandığı ortaya çıkmışır. Fakat artık hayatımızda her alanını etkileyen sosyal medyayı daha erken çağlarda, öğrencilerin daha anlamlı amaçlar için kullanmaları konusunda eğitimsel faaliyetler düzenlenebilir. Ayrıca öğrencilerin sosyal sermaye birikimleri incelendiğinde büyük bir çoğunluğunun bağlayıcı sosyal sermayeye sahip olduğu ortaya çıkmıştır. 
Araştırma sonuçları incelendiğinde bireylerin aktif demokratik davranışlara sahip olmasının göstergelerinden biri de sosyal sermaye birikimlerine sahip olmasıdır. Dolayısıyla bireylerin sosyal sermaye birikimlerinin artması erken çağlardaki eğitimsel tedbirlerle gerçekleşebilir. Örneğin, çevrenin korunmasında bilinçlendirme, gönüllü faaliyetler katılımın özendirilmesi ve hepsinden önemlisi işbirliği becerisinin ve bilincinin geliştirilmesi gereklidir.

Yapılan araştırmada nitel boyutta oldukça zengin veri elde edilmiştir. Fakat araştırmanın kapsamı çok geniş olduğu için bazı fenomenlere yönelik derinlemesine bilgi edinilme ihtiyacını doğurmuştur. Örnek olarak araştırma sonuçlarında üniversite öğrencilerinin siyasal sisteme karşı güvensizliği ortaya çıkmıştır ama bunun sebepleri irdelenememiştir. Ayrıca başka bir araştırma bulgusu da öğrencilerin bağlayıcı sosyal sermayeye sahip olduğudur. Öğrencilerin neden kaynaştıııcı sosyal sermayeye sahip olmadığı derinlemesine incelenmesi gerekmektedir.

\section{Kaynakça}

AveG. (2016). Türkiye'deki kurumlara güven anketi. http://www.agarastirma.com.tr/arastirmalar /kurumlara-guven-anketi/

Babacan, M. E., Haşlak, i. ve Hira, i. (2011). Sosyal medya ve Arap baharı. Akademik incelemeler Dergisi, 6(2), 63-92.

Bacanlı, H. (2015). Bilgi psikolojisi denemesi. İstanbul: Açılım Kitap.

Choi, D. H., ve Shin, D. H. (2017). A dialectic perspective on the interactive relationship between social media and civic participation: the moderating role of social capital. Information, Communication ve Society, 20(2), 151-166.

Coleman, J. (1988). Social capital in the creation of human capital. American Journal of Sociology, 94 , 95-120.

Çankaya, H. i. ve Çanakçı, H. (2011). Sosyal sermaye ve motivasyona yönelik öğretmen görüşlerinin değerlendilmesi, Milli Eğitim, 191, 127-134.

Çelik V. ve Ekinci, A. (2012). The effect of social capital on school success. International Journal of Social Sciences and Education. 2(1), 211-223.

Dalton, R. J. (2008). Citizenship norms and the expansion of political participation. Political Studies, $56,76-98$.

Ekinci, A. (2008). Genel liselerde sosyal sermaye düzeyinin ÖSS başarısına etkisi. Doktora Tezi. Fırat Ünivesitesi Sosyal Bilimler Enstitüsü.

Ekinci, A. ve Karakuş, M. (2011). Okul müdürlerinin sosyal sermaye liderliği davranışlarının öğretmenler arasındaki sosyal sermaye düzeyine etkisi. Kuram ve Uygulamada Eğitim Yönetimi, 17 (4), 527-553.

Ellison, N. B., Steinfield, C. ve Lampe, C. (2007). The benefits of Facebook "friends:" social capital and college students' use of online social network sites. Journal of Computer-Mediated Communication, 12, 1143-1168.

Ellison, N. B., Steinfield, C. ve Lampe, C. (2011). Connection strategies: Social capital implications of Facebook-enabled communication practices. New Media ve Society, 13, 873-892.

Erdoğan, í. (1999). Dördüncü gücün ilettiği: Amerikan örneği. K. Alemdar (der.). Medya gücü ve demokratik kurumlar. ss.33-43. Ankara: TUSES.

Granovetter, M. (1973). The strength of weak ties. The American Journal of Sociology, 78(6), 13601380.

Greenhow, C. ve Burton, L. (2011). Help from my "friends": Social capital in the social network sites of low-income students. Journal of Educational Computing Research, 45, 223-245. 
Güngör, G. (2011). Ilköğretim okullarının öğretmen görüşlerine göre sosyal sermaye düzeyleri ve dezavantajlılıkları ile ilgili değişkenler arasındaki ilişki (Mersin ili Mezitli ilçesi örneği). Yüksek Lisans Tezi. Mersin Üniversitesi Eğitim Bilimleri Enstitüsü.

Günkör, C. (2011). Sosyal sermaye ve eğitim ilişkisi. Yüksek Lisans Tezi. Gazi Ünivesitesi Eğitim Bilimleri Enstitüsü.

Hofer ve Aubert (2013). Perceived bridging and bonding social capital on Twitter: Differentiating between followers and followees. Computers in Human Behavior, 29, 2134-2142.

Howard, P. N., Duffy, A., Freelon, D., Hussain, M., Mari, W. ve Mazaid, M. (2011). Opening closed regimes: What was the role of social media during the Arab Spring?, http://pitpi.org/index.php/2011/09/11/opening-closed-regimes-what-was-the-roleof-social-media-during-the-arab-spring/

Hwang, H. ve Kim, K. O. (2015). Social media as a tool for social movements: the effect of social media use and social capital on intention to participate in social movements. International Journal of Consumer Studies, 39(5), 478-488.

Karasar, N. (2013). Bilimsel Araştırma Yöntemleri. Konya: Nobel.

Kassim, S. (2012). Twitter revolution: How the Arab Spring was helped by social media, http://mic.com/articles/10642/twitter-revolution-how-the-arab-spring-was-helped-bysocial-media, erişim 10/09/2015.

KONDA (2014). Gezi raporu 2014. http://www.konda.com.tr/tr/raporlar/KONDA GeziRaporu2014.pdf.

Korkmaz, M. (2014). Sosyal medya-kamu politikaları etkileşimi: Gezi parkı olayları üzerine bir değerlendirme. Yayınlanmamış yüksek lisans tezi. Hacettepe Üniversitesi, Sosyal Bilimler Enstitüsü.

Lerman, K., ve Ghosh, R. (2010). Information contagion: An empirical study of the spread of news on Digg and Twitter social networks. ICWSM, 10, 90-97.

Lin, N. (2005). A network theory of social capital. D. Castiglione, J. van Deth ve G. Wolleb (eds). Handbook on social capital. Oxford: Oxford University Press.

Newton, K. ve Zmerli, S. (2011). Three forms of social trust and their assosiation. European Political Science Review, 3(2), 169-200.

Newton, K. (2001). Trust, Social Capital, Civil Society, and Democracy. International Political Science Review 22(2), 201-214.

OECD (2001). The Well-Being of Nations, The Role of Human and Social Capital. Centre for Educational Research and Innovation, Paris: Organisation for Economic Co-operation and Development, http://www.oecd.org/dataoecd/36/40/33703702.pdf

Özdemir, Ç. (2007). Toplumsal değişme karşısında aile ve okul. Türk Eğitim Bilimler Dergisi. 5(2), 185 192.

Putnam, R. D. (2000). Bowling alone: The collapse and revival of American community. New York: Simon ve Schuster.

Ranieri, M., Manca, S. ve Fini, A. (2012). Why (and how) do teachers engage in social networks? An exploratory study of professional use of Facebook and its implications for life-long learning. British Journal of Educational Technology, 43(5), 754-769.

Reed, N. (2016). The influence of social media in Egypt during the Arap Spring, SIT Graduate Institute, http://digitalcollections.sit.edu/cgi/viewcontent.cgi?article=3986vecontext=capstones.

Steinfield, C., Ellison, N., ve Lampe, C. (2008). Social captial, self-esteem, and use of online social network sites: A longitudinal analysis. Journal of Applied Developmental Psychology, 29(6), 434-445. http://dx.doi.org/10.1016/ 
Van Deth, J. W. (2010). Participation in voluntary associations: Dark shades in a sunny World? American Behavioral Scientist, 53(5), 640-656.

Wolfsfeld, G., Segev, E. ve Sheafer, T. (2013). Social media and the Arab Spring politics comes first, The International Journal of Press/Politics, 18(2),115-137.

Yıldırım, A., ve Şimşek, H. (2011). Sosyal bilimlerde nitel arastırma yöntemleri. Seçkin Yayıncılık.

Yücel, C., Boyacı, A., Demirhan, G. ve Karataş, E. (2013). Milli Eğitim örgüt sisteminde 'kayıt alanı' (hinterland) uygulamasının yönetsel işlevselliğinin değerlendirilmesi ve ekonomik, sosyal ve kültürel sermaye açılarından doğurduğu problemlerin incelenmesi. Kuram ve Uygulamada Eğitim Yönetimi. 9(1), 135-151.

Zmerli, S. (2010). Social capital and norms of citizenship: An ambiguous relationship? Americal Behavioural Scientist. 53(5), 657-676. 


\section{Extended Summary}

The aim of the study is to investigate the relationship between social capital, social media use and democratic citizenship behaviors of university students studying at social science department at different Turkish state universities.

In vivid democracies, individuals act together with other individuals and/or voluntary organizations to solve some social, environmental, political and cultural problems. In doing so, the not only get personal satisfaction but also a common good for everybody. Those social or environmental problems are in the public eye more often than before owing to the fact that the internet and social media are actively used to create public opinion. Thus, it is important to look into the social media from the democracy and citizenship education research perspective.

Social capital theory asserts that; in healthy democratic societies, individuals have an interest in societal issues and act together to better any societal or environmental issues in cooperation with others. Societal issues are an integral part of politics and policy making process and the state have the power to draw and apply policies which can create culture. Because of its importance in both societal and political dimensions it is imperative to look at the relationship between social capital, social media and democratic citizenships behaviors. In this study, social science department students' democratic citizenship behaviors will be investigated by gathering data on their social capital, opinions about democracy, trust in democratic institutions, sources of information and aims of social media use.

The study is a part of a bigger research project. The big scale project was designed by utilizing both quantitative and qualitative approaches. Researchers gathered data from 2253 university students studying in 12 different state universities in Turkey during 2015-2016 spring semester. First stage of the study included quantitative data gathering by using several research tools. During quantitative data gathering stage, students were asked to give out their personal detail if they wish to be involved in qualitative part of the study. In total 46 students were volunteered. Among those 46 students, 12 were selected on the following criteria: first different university representation was priority, second both male and female students should be represented equally where possible, third, 3. and 4. graders should be selected for interviews and the last but not the least all of the students to be interviewed should be using social media actively, involved in political or cultural activities in students' clubs and other NGOs. One student did not participate in the interview, thus total number of students were 11 fort the qualitative data to be gathered.

The data gathered by using semi-structured interview schedule which included questions about their social media use, their involvement in political, cultural, environmental and educational issues, their trust in democratic institutions, social capital accumulation and their sources of knowledge.

The data was subject to content analysis. After data was transcribed, open codes were decided by the researchers. Then, axial coding stage came. However, there was not in-depth data for some issues to create a sound theoretical categorization. Then researchers opted to use the categories that were created after quantitative data analysis. By using this categories a meaningful themes and categories occurred.

According to analysis the following categories were emerged: democracy and citizenship, social capital, democracy, social media and sources of information. According to this categorization the findings can be summarized as: Students have both bonding and bridging social capital. They especially invest in and spent bonding social capital as it occurs among close friends, family members and likeminded people. Bridging social capital appears to occur by using internet facilities. As for the students' opinions towards democracy, their views fall into active citizenship features and trust in democratic institutions. They define democracy as liberty and equality. Their active citizenship features means their voting behavior, organized citizenship behaviors and involvement in civil society. 
When one analysis students' trust towards democratic institutions, it appears that no students trust none of the institutions. Only, some students expressed a little sympathy towards arm forces. The little trust they have could be accounted for armed forces struggle against terrorist activities in Turkey and their perceived guardianship of the republic. Students' sources of information are social media, authority, their own life experiences and scientific resources. Most of the students expressed that they use social media as the sources of information as it is easy to access and contains up-to-date information with reservation that the information that they get from social media needs to be validated from other sources. Other uses of social media are for networking, research, interaction with affiliated political group and fun. Analysis of data shows that all of the students use facebook, instagram, twitter actively and uses for multiple purposes. In addition another interesting finding is that students who are extreme political activists use social media to interact with other political groups other than their own group. This is especially is a need for them to organize political or environmental protest or petitions. 